\title{
ВИЗНАЧЕННЯ РОЛІ КОМУНІКАЦІЙ У ПУБЛІЧНОМУ УПРАВЛІННІ
}

\author{
Гавкалова Н. Л., Джаін Прадіп Кумар
}

\section{ВСТУП}

Глобалізаційні процеси, що супроводжуються розвитком інформаційного суспільства, спонукають до реформування і вдосконалення системи публічного управління в напрямку побудови «ефективної, прозорої, відкритої та гнучкої структури органів публічної влади із застосуванням новітніх комунікаційних інструментів, інформаційно-комунікативних технологій (е-урядування), які здатні виробляти і реалізовувати цілісну державну політику, спрямовану на суспільний сталий розвиток і адекватне реагування на внутрішні та зовнішні виклики ${ }^{1}$. Поняття публічного управління випливає 3 результату переосмислення державного управління і безпосередньо пов'язаних 3 побудовою демократичної держави. Специфіка державного управління полягають в досягненні пріоритетних цілей держави, в той час як публічне управління служать засобом вираження суспільних інтересів, яке виступає як результат суспільного договору між суспільством і державою згідно з яким відбувається розподіл владних повноважень між органами публічної влади та інститутами громадянського суспільства. Отже, сучасна політика являє собою публічну сферу взаємодії суб’єктів, яка відбувається завдяки комунікативній природі політики.

Значну увагу питанням ефективних комунікацій у сфері публічного управління присвячено праці таких зарубіжних та вітчизняних дослідників, як Г. Алмонд, О. Амосов, М. Андріїв, В. Бакуменко, Н. Гавкалова, С. Ганущин, I. Грицяк, Т. Джига, Г. Дзяна, К. Дойч, В. Дрешпак, В. Загорський, В. Князєв, С. Кривокора, В. Куйбіда, Г. Лассуелл, Н. Луман, Г. Почепцов, С. Соловйов, Ю. Хабермас, I. Шавкун, У. Шрамм та інші. Зважаючи на великий науковий доробок зазначених вчених у вирішенні широкого спектру актуальних питань, що пов'язані з комунікативною взаємодією органів публічної влади,

\footnotetext{
${ }^{1}$ Стратегія сталого розвитку «!Україна - 2020» [Текст] : схвалена Указом Президента України № 5/2015 від 12.01.2015 p. URL : https://zakon.rada.gov.ua/laws/show/5/2015 (дата звернення:: 28.12.2020).
} 
поза увагою залишається вивчення ролі комунікацій в публічному управлінні.

Аргументи, наведені вище, стали основою для визначення мети дослідження, а саме обгрунтування ролі комунікації в публічному управлінні, визначення напряму комунікативної стратегії органів публічного управління.

Для досягнення поставленої мети необхідно вирішити такі завдання:

- розглянути природу комунікацій в публічному управлінні;

- сформувати алгоритм впровадження коректного вибору відповідної комунікаційної стратегії органів публічної влади.

Обгрунтування ролі комунікацій в публічному управлінні, пов'язане насамперед 3 демократизацією суспільного життя, що передбачає відкритість публічних органів влади, формування партнерських відносин між органами публічної влади і суспільством, де суспільство розглядається не тільки як об'єкт впливу, а й як учасник в побудові нових демократичних відносин.

\section{1. Обгрунтування природи комунікації в публічному управлінні}

Комунікація як засіб передачі інформації від людини до людини розвивалася разом з суспільством, як інструмент політичного впливу (ідеологічного інструменту) осмислювалася вже в далекій давнині. Так, спроби контролювати інформаційні потоки, спрямувати комунікацію в потрібне русло, інститутами влади робилися за допомогою видання указів і законів.

Власне, і сам термін «комунікація» в його нинішньому розумінні закріпився в понятійно-категоріальному апараті відносно недавно. Вперше в політологічному контексті було вжито в рамках політичної географії на початку XX ст. німецьким вченим Ф. Ратцелем. Як вважає У. Шрамм, комунікації $є$ основним засобом структурування соціального простору, «визначаючи статусні і пізнавальні характеристики його учасників»².

Процес комунікації включає не тільки безпосередній, але i опосередковану передачу інформаційних сигналів, тому представляючи собою різноспрямований процес, вимагає його осмислення в рамках різних наукових підходів. Ураховуючи змістовний аспект комунікацій, можна виділити три концептуальні підходи (табл. 1).

Ю. Хабермас із позиції некласичної парадигми висловив зміст комунікації як «... процесуально-творчої, діяльнісної форми спілкування, яка спрямована на вироблення нових цілей і творчість,

\footnotetext{
${ }^{2}$ Schramm W. The process and effects of mass communication. University of Illinois Press, Urbana, 1954. 586 р. (дата звернення: 28.12.2020).
} 
основою діалогу суб'єктів якої є взаємна інтерпретація, а саме взаєморозуміння, тобто згода (consensus), яка, на думку автора, пов'язується із придбанням суб'єктами процесу універсальної комунікаційної компетенції через мовну передачу смислуз ${ }^{3}$.

Таблиця 1

Концептуальні підходи щодо аспекту комунікацій

\begin{tabular}{|l|l|}
\hline \multicolumn{1}{|c|}{ Концептуальні підходи } & \multicolumn{1}{c|}{ Характеристика } \\
\hline Класична позитивістська & - односпрямований характер комунікації \\
парадигма & не вимагав наявності «зворотного зв’язку», \\
Перша половина ХІХ ст. & орієнтуючись на оцінку якості обраного \\
(О. Конт, Г. Спенсер) & комунікаційного каналу. Результат \\
& комунікаційної взаємодії залежав виключно \\
& від особистісних і професійних \\
& характеристик інформатора - джерела \\
& інформації, грунтується на системних \\
& зв'язках і функціях. \\
\hline Некласична парадигма & - процес комунікації оцінювався як \\
(Е. Гуссерль, & особлива форма спілкування, взаємодія \\
М. Мерло-Понті), & соціальних суб'єктів в умовах наявності \\
(теорія комунікативної дії & різних можливостей і потреб; творчої \\
(Ю. Хабермас)) & співпраці на основі рівноправності і \\
& ціннісних орієнтацій. Вперше розкрита роль \\
& масової комунікації яка трактується як \\
& процес не тільки зв’язку, але й передачі \\
& інформації групі людей за допомогою \\
спеціальних засобів масмедіа.
\end{tabular}

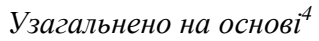

3 Хабермас Ю. Моральное сознание и коммуникативное действие. СанктПетербург, 2000. 176с. (дата звернення: 28.12.2020).

${ }^{4}$ Lasswell H. Propaganda technique in the World War. London, 1927. Р. 137 (дата звернення: 28.12.2020).

Schramm W. The process and effects of mass communication. University of Illinois Press, Urbana, 1954. 586p. (дата звернення: 28.12.2020).

Хабермас Ю. Моральное сознание и коммуникативное действие. СанктПетиербург, 2000. 176с. (дата звернення: 28.12.2020). 
Н. Луман, продовжуючи осмислення теорії Ю. Хабермаса, відзначив, що смислове значення комунікації відзначається ії здатністю реалізовуватися у формі рішень. Успіх комунікації, на думку автора, залежить від сприйняття одержувачем селективного змісту інформації5.

Представник пост некласичного етапу Г. Хакен особливу роль надає інформації як вирішального елементу, різнонаправлений характер якої породжує конкуренцію чи кооперацію, результатом якої є вироблення загальних для всіх елементів системи параметрів порядку. Розвиток будь-якої системи стає можливим лише за умови перманентного обміну інформацією між різними частинами системи ${ }^{6}$.

Структурно-функціональна модель політичної системи, що запропонована М. Грачевим, визначає комунікацію компонентом, що забезпечує гомеостатичну стійкість політичної системи як цілісного утворення, що знаходиться в безперервній взаємодії зі змінною соціальним середовищем. Ключові елементи політичної системи пов'язані між собою за допомогою складної мережі політичних комунікацій, які виступають способом, засобом існування і передачі інформації в рамках різних моделей комунікації

Е. Тоффлер, визначаючи визначальну роль політичних комунікацій, вказує, що в умовах поширення-інформаційних технологій, комунікативні можливості суспільства істотно зростають. На зміну інтрарозумним мережам, що містять кілька комунікативних каналів, в тому числі зворотний зв'язок, приходять екстрарозумні мережі, що мають здатність самостійного перекодування i зміни інформації (з точки зору її обсягу і змісту) без участі відправника та одержувача ${ }^{8}$.

Щоб виявити сутність і природу комунікації, розглянемо дане поняття з точки зору різних теоретичних підходів (табл. 2).

До розгляду ролі комунікацій в публічному управлінні, з точки зору інформаційного та кібернетичного підходу, відноситься робота К. Шеннона i У. Уівера «Математична теорія комунікацій». Особливість цього підходу полягає в розгляді комунікації як ключової

5 Хабермас Ю. Моральное сознание и коммуникативное действие. СанктПетербург, 2000. 176с. (дата звернення: 28.12.2020).

5 Луман Н. Власть. Пер. с нем. А. Ю. Антоновского. Москва : Праксис, 2001. С.104. (дата звернення: 28.12.2020).

6 Хакен Г. Информация и самоорганизация: макроскопический подход к сложным системам: пер. с англ. - 3-е изд., испр. и знач. доп. Москва : URSS: Ленанд, 2014. С.45 (дата звернення: 28.12.2020).

${ }^{7}$ Грачев М.Н. Политическая коммуникация: теоретические концепции, модели, векторы развития: Монография. Москва : Прометей, 2004. С. 48. (дата звернення: 28.12.2020).

${ }^{8}$ Тоффлер Э. Метаморфозы власти Пер. с анг. Москва : ООО «Изд-во АСТ», 2003. С. 145. (дата звернення: 28.12.2020). 
складової частини будь-якої системи, де управління цією системою заснована на принципі зворотного зв'язку'.

Таблиця 2

Визначення дефініції «комунікація» 3 виділенням

ії ключових компонентів в рамках різних підходів

\begin{tabular}{|c|c|c|c|c|c|c|c|c|c|c|}
\hline \multirow[b]{2}{*}{ Автори } & \multicolumn{5}{|c|}{ Ключові компоненти } & \multicolumn{5}{|c|}{ Підхід } \\
\hline & 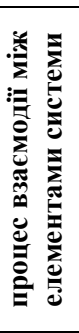 & 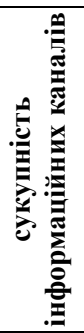 & 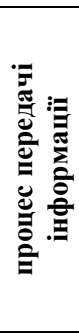 & 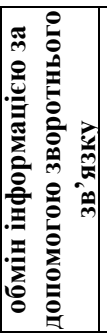 & 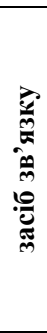 & & & 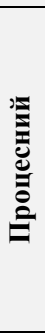 & 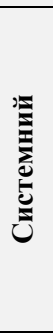 & 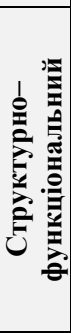 \\
\hline Г. Алмонд & + & & & & & & & & + & \\
\hline Н. Вінер & & & + & & & & + & & & \\
\hline К. Дойч & + & & & & & & + & & & + \\
\hline В. Дрешпак & & & & + & & & & + & & \\
\hline М. Грачев & + & + & & + & + & & & & & + \\
\hline В. Загорський & & + & & & & & & & & + \\
\hline Е. Кривокора & + & & & & + & & & + & & \\
\hline Дж. Лейхіфф & & + & & & & & & & & \\
\hline В. Нейман & & & + & & & & & & & + \\
\hline Р. Пушкарьова & & & & + & & + & & & & \\
\hline Т. Парсонс & + & & & & & & & & + & + \\
\hline Е. Роджерс & & & & + & & & + & & & + \\
\hline Э. Тоффлер & + & + & & + & & + & & & & \\
\hline К. Шеннон & + & & + & + & & + & + & & & \\
\hline I. Яковлев & + & & & & & & + & & + & \\
\hline
\end{tabular}

Узагальнено на основі ${ }^{10}$

${ }^{9}$ Weaver W., Shannon C. E. The mathematical theory of communication Univ. Of Illinois Press, 1963. С. 35. (дата звернення: 28.12.2020).

${ }^{10}$ Lasswell H. Propaganda technique in the World War. London, 1927. 250 p. (дата звернення: 28.12.2020).

Хабермас Ю. Моральное сознание и коммуникативное действие.СПб., 2000. 176 с. (дата звернення: 28.12.2020).

Луман Н. Власть. Пер. с нем. А. Ю. Антоновского. Москва : Праксис, 2001. 256 с. (дата звернення: 28.12.2020).

Хакен Г. Информация и самоорганизация: макроскопический подход к сложным системам: пер. с англ. - 3-е изд., испр. и знач. доп. Москва : URSS: Ленанд, 2014. 317 с. (дата звернення: 28.12.2020). 
Кібернетичний підхід полягає в розгляді комунікації як ключової складової частини будь-якої системи (в тому числі політичної), а управління цією системою засновано на принципі зворотного зв'язку (позитивної або негативної). В основі кібернетичного підходу лежить вивчення комунікацій як саморегульованих систем, де основним принципом кібернетики $\epsilon$ зворотній зв'язок, який $\epsilon$ ключовим у сучасному розумінні політичного управління. На думку К. Дойча, який із позиції кібернетичного підходу описував природу комунікації, уряд, який є суб'єктом публічного управління, мобілізує політичну систему за допомогою контролю інформаційних потоків і комунікативних взаємодій середовища і системи, а також окремих елементів всередині цієї системи ${ }^{11}$. В рамках цього підходу І. Яковлев визначає комунікацію як процес взаємодії між комунікаторами як елементами соціальних систем ${ }^{12}$.

Розглядаючи комунікацію під кутом зору системного підходу, дослідники говорять про нерозривну єдність апарату органів публічної влади із середовищем, взаємодію з яким вона виявляє свою цілісність, виходячи із принципів ієрархічності, багаторівневості, що характеризують будову політичної системи суспільства ${ }^{13}$.

Грачев М.Н. Политическая коммуникация: теоретические концепции, модели, векторы развития: Монография. Москва : Прометей, 2004. С. 328. (дата звернення: 28.12.2020).

Тоффлер Э. Метаморфозы власти Пер. с анг. Москва : ООО «Изд-во АСТ», 2003. 669 с. (дата звернення: 28.12.2020).

Weaver W., Shannon C. E. The mathematical theory of communication Univ. Of Illinois Press, 1963.131 р. (дата звернення: 28.12.2020).

Deutsch K. W. The Nerves of Government: Models of Political Communication and Control. London, Free Press of Glencoe, 1963. 316 p.

Яковлев И.П. Ключи к общению. Основы теории коммуникаций. СанктПетербург : Институт управления и экономики, 2001. 230 с. (дата звернення: 28.12.2020).

Алмонд Г., Верба С. Гражданская культура: политические установки и демократия в пяти странах. Москва : Мысль, 2014. 500 с. (дата звернення: 28.12.2020).

Парсонс Т. Система современных обществ. Москва : Аспект-ІІресс, 1998. 270 с. (дата звернення: 28.12.2020).

Дрешпак В.М. Комунікації в публічному управлінні : навч. посіб. Дніпро : ДРІДУ НАДУ, 2015. 168 с. (дата звернення: 28.12.2020).

${ }^{11}$ Deutsch K. W. The Nerves of Government: Models of Political Communication and Control. London, Free Press of Glencoe, 1963. 316 р. (дата звернення: 28.12.2020).

12 Яковлев И. П. Ключи к общению. Основы теории коммуникаций. СанктПетербург : Институт управления и экономики, 2001. С. 44. (дата звернення: 28.12.2020).

13 Меркулов И. Когнитивная эволюция. Рос. акад. наук. Ин-т философии. Москва : РОССПЭН. С.27. (дата звернення: 28.12.2020). 
Найважливішу роль комунікації підкреслюють Г. Алмонд і Дж. Коулман, де системний підхід підкреслює велике значення зворотного зв'язку, що дозволяє владі отримувати достовірну та актуальну інформацію про реакцію суспільства на рішення, що приймаються, і відповідно до цього - коригувати їх, створювати основу для прийняття нових рішень. Політичні рішення представляються як результат обробки вхідної інформації. Механізм зворотного зв'язку, таким чином, забезпечує контроль і розвиток політичної системи ${ }^{14}$.

Досліджуючи політичну систему на основі системного підходу, К. Дойч розробив інформаційно-кібернетичну концепцію, де вченим виділено чотири фази руху інформації: надходження інформації; аналіз; прийняття рішення; реалізація рішення і отримання зворотного зв'язку. Відповідно до системного підходу в комунікативній системі елементи мають певні властивості і функціями, між якими всередині системи $€$ зв'язки і взаємодію із зовнішнім середовищем ${ }^{15}$.

Системний підхід пов'язаний 3 ім'ям Т. Парсонса, який стверджував, що основною властивістю соціальної системи $є$ наявність загальноприйнятих символів і правил поведінки. Дійова особа (актор), будучи частиною певної культурної системи (а також його поведінкова система, засвоєна за допомогою навчання), має риси, спільні з іншими особистостями, наприклад мову, на якому він звик говорити. При цьому комунікативна взаємодія $\mathrm{T}$. Парсонс трактує як процес соціальних інтеракцій, за допомогою якого відбувається інтеграція індивідів в суспільство ${ }^{16}$.

Зазначаючи видом управлінської діяльності $Г$. Меньшикова розглядає комунікацію в публічному управлінні як процес взаємообміну політичної інформацією індивідів і груп на всіх рівнях управління з метою досягання між ними згоди ${ }^{17}$.

Також процесом обміну інформацією в соціумі розглядає Г. Пушкарьова, акцентуючи увагу на зацікавленість усіх сторін

14 Алмонд Г., Верба С. Гражданская культура: политические установки и демократия в пяти странах. Москва : Мысль, 2014. С. 27 (дата звернення: 28.12.2020).

${ }^{15}$ Deutsch K. W. The Nerves of Government: Models of Political Communication and Control. London, Free Press of Glencoe, 1963. 316 p.

16 Парсонс Т. Система современных обществ. Москва : Аспект-Пресс, 1998. С. 32 (дата звернення: 28.12.2020).

17 Меньшикова Г. А. Управление как вид коммуникации. Социальные коммуникации и информации исследования, образование, практика: материалы Межвузовской научно-практической конференции (11-12 ноября 1999 г., Санкт Петербург). Санкт-Петербург : ООО «Петрополис», 1999. С. 23. (дата звернення: 28.12.2020). 
комунікаційного процесу, яке визначаючим у досягненні ефективності

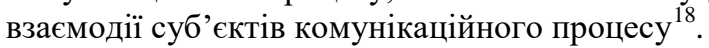

Розділяючи думку попередніх вчених щодо визначення комунікації, В. Мазур доповнює, що комунікація об'єднує в єдине ціле органи публічного управління та групи громадськості. Перевагою ефективних комунікацій $є$ те, що вона зміцнює необхідний зворотний зв'язок між адміністративним апаратом, управлінськими структурами, суспільством, окремими громадами й індивідами, $\epsilon$ важливим чинником демократизації суспільного життя ${ }^{19}$.

Розглядаючи комунікацію в масштабах держави, Д. Погорєлий визначає iї процесом взаємодії між елементами політичної системи, соціальними суб'єктами, державою та суспільством шляхом обміну інформацією безпосередньо або за допомогою телебачення, радіо, преси, мережі Інтернет тощо ${ }^{20}$.

В.М. Бебик відмічав, що комунікація виконує дуже важливі функції в суспільному житті, створюючи умови для забезпечення роботи не тільки інформаційної, але і суспільної сфери. Без комунікацій функціонування економічної, соціальної, політичної та духовної сфер суспільства неможливе ${ }^{21}$.

Комунікативна діяльність у публічному управлінні полягає уздійсненні інформаційних обмінів, спрямованих на виконання функцій публічного управління, i забезпечується комунікативною підсистемою публічного управління ${ }^{22}$.

Існують різні підходи до визначення функцій комунікативної діяльністі. Так, А. Мельник, А. Васіна, Н. Кривокульська стверджують, що «здійснення комунікацій в державних установах і організаціях

18 Пушкарева Г. В. Политический менеджмент в системе управленческих отношений современного общества. Вестник Моск. ун-та. Сер. 21. Управление (государство и общество). 2005. № 3. С. 62. (дата звернення: 28.12.2020)

19 Мазур В.Г. Комунікації як механізм взаємодії державних органів влади та громадськості на регіональному рівні. Електронний журнал «Державне управління: удосконалення та розвиток». URL: http://www.dy.nayka.com.ua/ ?op=1\&z=313 (дата звернення: 28.12.2020).

${ }^{20}$ Погорелый Д. Политология / под общ. ред С.Н. Смоленского. Москва : Эксмо, 2008. С. 47 (дата звернення: 28.12.2020).

21 Бебик В.М. Інформаційно-комунікаційний менеджмент у глобальному суспільстві: психологія, технології, техніка паблік рилейшнз : монографія. Київ : МАУП, 2005. С. 31 (дата звернення: 28.12.2020).

22 Дрешпак В. М. Комунікації в публічному управлінні : навч. посіб. Дніпро : ДРІДУ НАДУ, 2015. С. 12-13 (дата звернення: 28.12.2020). 
покликано забезпечити виконання наступних функцій : інформаційної; мотиваційної, контрольної, експресивної» ${ }^{23}$.

Із позицій структурно-функціонального розгляду комунікативної підсистеми публічного управління та комунікативної діяльності в публічному управлінні можемо виділити чотири притаманні їм основні складові (підсистеми) ${ }^{24}$ (рис. 1).

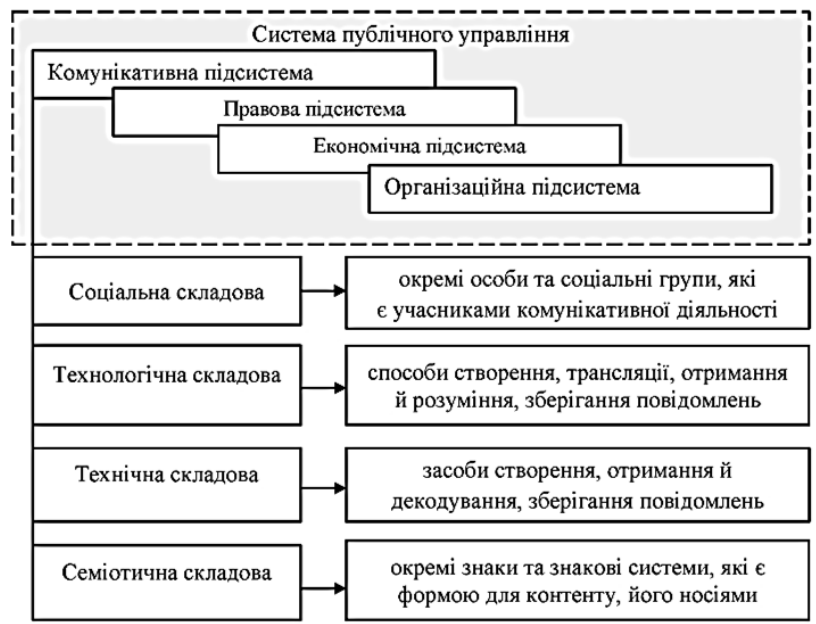

\section{Рис. 1. Складники комунікативної підсистеми публічного управління}

Комунікації покликані виконувати такі функції, як: дослідницькі; планування; організаторські; експертні, які прявляються в оцінці ефективності проведеної роботи i виявленні нових проблем, які необхідно буде вирішувати ${ }^{25}$.

Аналітико-прогоностичну, організаційно-управлінську, комунікативно-інформаційну i консультативно-методичну функції комунікативної діяльності виокремлює А. Звєрінцев ${ }^{26}$.

${ }^{23}$ Мельник А.Ф. Менеджмент державних установ і організацій : навч. Посіб / За ред. А.Ф. Мельник. Київ : ВД «Професіонал», 2006 р. С. 33 (дата звернення: 28.12.2020).

24 Дрешпак В.М. Комунікації в публічному управлінні : навч. посіб. Дніпро : ДРІДУ НАДУ, 2015. 168 с. (дата звернення: 28.12.2020).

${ }^{25}$ Шарков Ф.И. Политический консалтинг : учеб. пособ. Москва : Издательскоторговая кооперация «Дашков и К», 2004. С. 27 (дата звернення: 28.12.2020).

26 Зверинцев А.Б. Коммуникационный менеджмент : рабочая книга менеджера PR.2-е изд., испр. Санкт-Петербург : Союз, 1997. С. 18. (дата звернення: 28.12.2020). 
А. Соловйов зазначає, що інформаційні зв'язки є базовими для політичної практики комунікацій i в сукупності формують інформаційно-комунікативні системи ${ }^{27}$.

Функції комунікативної підсистеми публічного управління можна поділити на внутрішні та зовнішні функції цієї підсистеми ${ }^{28}$ (табл. 3).

Таблиця 3

Функції комунікативної підсистеми публічного управління

\begin{tabular}{|c|c|}
\hline $\begin{array}{c}\text { Внутрішні функції } \\
\text { комунікативної підсистеми } \\
\text { публічного управління }\end{array}$ & $\begin{array}{c}\text { Зовнішні функції } \\
\text { комунікативної підсистеми } \\
\text { публічного управління }\end{array}$ \\
\hline $\begin{array}{l}\text { формування та підтримання } \\
\text { усталених комунікативних } \\
\text { зв’язків між елементами системи } \\
\text { публічного управління та ними } \\
\text { й елементами середовища; } \\
\text { виробництва та зберігання значень } \\
\text { i смислів, носіями яких є елементи } \\
\text { їі семіотичної підсистеми, що } \\
\text { забезпечує генерування та } \\
\text { збереження управлінської } \\
\text { інформації, а також створює } \\
\text { «ідейно смисловий каркас» } \\
\text { системи публічного управління. }\end{array}$ & $\begin{array}{l}\text { трансляційна, що полягає } \\
\text { у використанні встановлених } \\
\text { комунікативних зв'язків для здійснення } \\
\text { обмінів повідомленнями } \\
\text { у внутрішньому та зовнішньому } \\
\text { середовищі; } \\
\text { номінативна, що полягає у } \\
\text { відображенні через певні семіотичні } \\
\text { елементи предметів, явищ і процесів, } \\
\text { притаманних системі публічного } \\
\text { управління; } \\
\text { соціального управління, що полягає } \\
\text { у використанні комунікативних засобів } \\
\text { для спрямування діяльності людей, } \\
\text { забезпечення її ціннісного наповнення. }\end{array}$ \\
\hline
\end{tabular}

Таким чином, перебуваючи у стані динамічної взаємодії з іншими підсистемами публічного управління (організаційною, правовою, економічною, іншими), комунікативна підсистема публічного управління, де виділяються внутрішні та зовнішні функції публічного управління, охоплює суб'єктів управління взаємодії між собою та 3 іншими суспільними інститутами, складається 3 низки підсистем нижчого рівня, що і власне формують їі структуру.

\section{2. Комунікативні стратегії органів публічного управління}

Демократичний характер публічного управління передбачає формування ефективних відносин суспільства і держави, перш за все як рівноправних партнерів в процесі управління. Одним із напрямків

27 Соловьев А. И. Политическая коммуникация: к проблеме теоретической идентификации. Полис. 2002. № 3. С. 6. (дата звернення: 28.12.2020).

28 Дрешпак В. М. Комунікації в публічному управлінні : навч. посіб. Дніпро : ДРІДУ НАДУ, 2015. 168 с. (дата звернення: 28.12.2020). 
розвитку ефективних відносин $\epsilon$ широке впровадження у процеси управління результатів досягнення в галузі інформаційно-комунікаційних технологій та програмного забезпечення, із застосуванням технологій «електронного уряду», «електронної демократії».

У даний час здійснюється інтенсивне впровадження інформаційнокомунікаційних технологій в діяльність публічного управління. Джерелами формування інформаційного суспільства прийнято вважати концептуальні, основи, які були закладені в працях класиків теоретиків постіндустріального (інформаційного) суспільства. Відзначимо, що діяльність органів публічного управління пов'язана 3 безперервною циркуляцією інформації, де комунікаційний процес в публічному управлінні представлений трьома підсистемами: керуючою підсистемою, що включає в себе державні структури, які відповідають за ефективність прийняття і реалізації управлінських рішень, керованою підсистемою - громадянське суспільство, суб'єкти підприємницької діяльності, професіонали в конкретній галузі компетенцій, що втягуються в процес формування та аналізу альтернатив, що розглядаються в процесі прийняття суспільно значущих управлінських рішень, підсистема інформаційнокомунікаційної взаємодії - це прямі і зворотні, горизонтальні і вертикальні діалогові взаємини різноманітних інститутів громадянського суспільства, держави і бізнесу. Результативність системи публічного управління корелює з ефективністю виконання принципу зворотного зв'язку, що зумовлює потенціал системи до адаптації до трансформацій у зовнішньому середовищі (рис. 2).

На думку П. Друкера, процес комунікації не залежить від змісту інформації. По суті, ідеальні комунікації повинні представляти собою «обмін досвідом» в чистому вигляді. Головна умова ефективного спілкування - правильне сприйняття, а не інформаційна насиченість ${ }^{29}$.

Отже, велику увагу необхідно приділити такому структурному елементу комунікаційного процесу, як канал зв'язку, який виступає засобом передачі інформації, а отже, від впровадження інформаційнокомунікаційних технологій, використання якого можна отримати такі переваги, як зниження тимчасових витрат, запобігання випадків спотворення інформації, поліпшення ефективності управління комунікаційним процесом.

29 Друкер, Питер, Ф. Энциклопедия менеджмента. : Пер. с англ. Москва : Издательский дом «Вильямс». 2004. 321 с. (дата звернення: 28.12.2020). 
Інформаційна середовише системи публічного управління

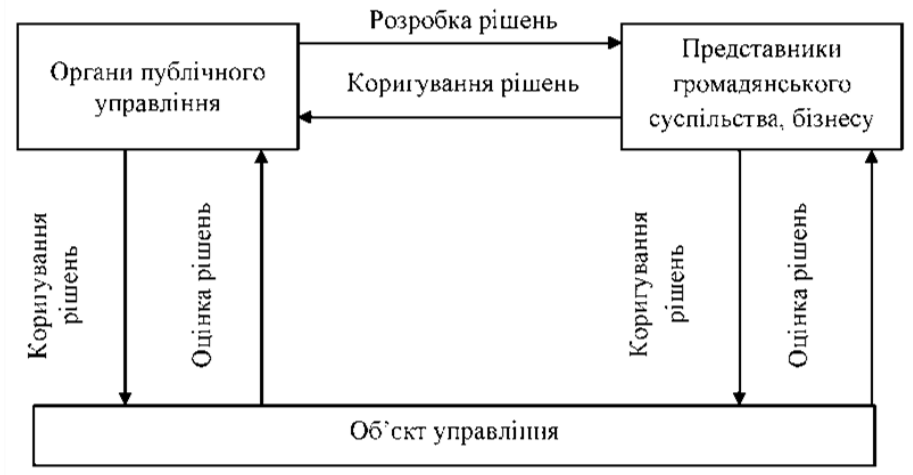

Рис. 2. Комунікаційних процес у системі публічного управління

У сучасних умовах впровадження інформаційно-комунікаційних технологій представляється можливим використання нових інструментів підвищення гласності, відкритості, транспарентності системи публічного управління, що сприяють активному залученню громадянського суспільства і бізнес-структур до процесу публічного управління не тільки з метою здійснення функції контролю щодо діяльності органів державної влади, а й використання інтелектуального потенціалу населення з метою вирішення соціально значущих проблем.

Важливим $є$ формування комунікаційної стратегії, яка передбачає використання таких заходів:

- раціоналізація структури комунікаційного процесу шляхом усунення зайвих та дублюючих функцій та операцій, об'єктивна оцінка трудомісткості окремих управлінських функцій;

- регулювання інформаційних потоків шляхом встановлення обсягів та пріоритетів інформаційного обміну за встановленими напрямами з врахуванням пропускної здатності каналів зв'язку;

- вдосконалення документообігу;

- удосконалення організаційної структури управління шляхом усунення зайвих бюрократичних процедур;

- застосування сучасних інформаційних технологій та оновлення технічної інфраструктури, що сприятиме формуванню електронної демократії ${ }^{30}$.

${ }^{30}$ Шпак Н.О. Основи комунікаційного менеджменту промислових підприємств. Львів : Видавництво Львівської політехніки, 2011. 328 с. (дата звернення: 28.12.2020). 
С. Кліфт описує електронну демократію як застосування інтернеттехнологій 3 метою розширення громадянських прав і свобод, можливостей участі в дискусіях незалежно від соціального статусу i територіального розташування ${ }^{31}$.

Виділяють 4 ступені розвитку електронного уряду:

1) «Каталог»: розміщення офіційної інформації і документів онлайн на сайтах органів державної влади;

2) «Трансакції»: онлайн-сервіси та форми звернень і заяв;

3) «Вертикальна інтеграція»: обмін даними всередині ієрархії владних структур, подальший розвиток призначених для користувача сервісів;

4) «Горизонтальна інтеграція»: міжвідомча комунікація, створення сервісів «єдиного вікна» ${ }^{32}$.

Для реалізації та регуляції алгоритму комунікаційної стратегії органів публічної влади необхідно володіти спеціальними знаннями в даній області, що зумовлює розвиток особистісних i професійних якостей керівників публічних інституцій. Базова конфігурація алгоритму комунікаційної стратегії органів публічної влади передбачає такі етапи (рис. 3).

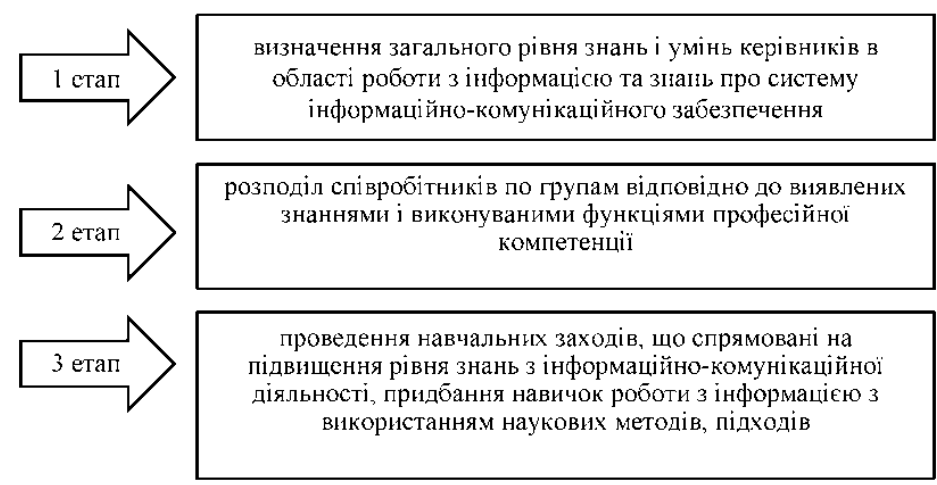

Рис. 3. Етапи, що передбачають впровадження алгоритму комунікаційної стратегії органів публічної влади

${ }^{31}$ Clift S. Putting, Pen to Paper: Electronic Democracy, Write On! 1996. URL : https://stevenclift.com/putting-pen-to-paper-electronic-democracy-write-on-by-stevenclift-1996/ (дата звернення: 28.12.2020).

32 Дьякова Е.Г. Переход к электронному правительству: теоретические модели и национальные практики. Дніпропетровськ. Вісник Дніпропетровського Університету. 2013. С. 23. (дата звернення: 28.12.2020). 
Отже, ефективна діяльність органів публічної влади в сучасних умовах вимагає від персоналу знань у сфері інформаційнокомунікаційних технологіях. О. Амосов зазначає, що діяльність державного службовця чи посадової особи органу публічного управління сьогодні реалізується в мережевому комп'ютерному середовищі, що безупинно розвивається. Це потребує формування сучасної інформаційної культури державних службовців, зумовлює необхідність використання глобальних мереж Internet $\mathrm{i}$ широке запровадження VPN. Розвиток комп'ютерного комплексу управління має сприяти формуванню інформаційного технополісу із новітньою інфраструктурою та відповідної навчальної бази, випереджальних темпів інформатизації управлінської освіти й науки. Інформаційні технології розглядаються у світі і як важливий чинник розв'язання проблем державної кадрової політики ${ }^{33}$.

Загальний алгоритм впровадження коректного вибору відповідної комунікаційної стратегії такий (рис. 4):

- підготовчий етап - аналіз ринку наявних автоматизованих систем, програм;

- етап проектування - постановка цілей та визначення можливостей у разі відхилення від планованих завдань, повернення до першого кроку алгоритму;

- впровадження та регуляція стратегії - реалізація плану заходів у разі відхилення від планованих завдань, повернення до першого кроку алгоритму;

- експлуатація - аналіз результатів реалізації алгоритму, підсумковий звіт.

Запропонований алгоритм комунікаційної стратегії дозволить оптимізувати процеси вибору впровадження і застосування кращих ІКТ-рішень, підвищити ефективність їх використання, що дозволить безперервно удосконалювати діяльність органів публічної влади за рахунок орієнтації даної системи на постійне поліпшення, оскільки:

по-перше, в роботі з розвитку ІКТ безпосередньо бере участь керівництво владних установ, що безперечно полегшує і прискорює втілення в життя необхідних перетворень. Керівник виступає координатором експертної ради та свого роду арбітром виникаючих суперечок;

33 Амосов О. Електронне урядування - альтернативи не має! Новітні інформаційно-комунікаційні технології в модернізації публічного управління: зарубіжний і вітчизняний досвід : матеріали II наук.- практ. семінару, (25 квітня 2014 р., м. Дніпропетровськ) / редкол. : В.М. Дрешпак (голов. ред.). Дніпро : ДРІДУ НАДУ, 2014. С.6 (дата звернення: 28.12.2020). 


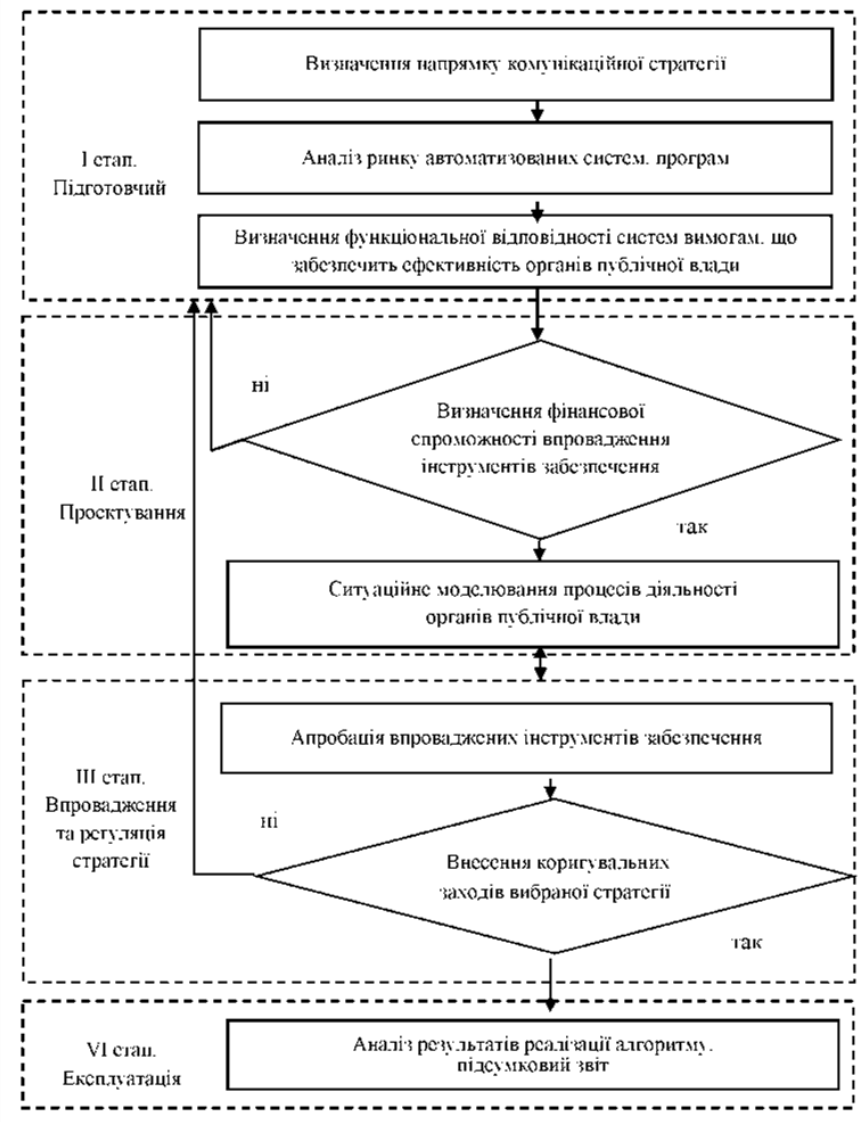

\section{Рис. 4. Алгоритм впровадження коректного вибору відповідної комунікаційної стратегії органів публічної влади}

по-друге, до роботи залучені всі зацікавлені сторони, що дозволяє забезпечити баланс інтересів користувачів IКТ, всебічно вивчати поставлені завдання і знаходити найоптимальніші їх вирішення;

по-третє, електронний документообіг полегшує процедуру прийняття рішень, дозволяє фіксувати весь життєвий цикл управлінського рішення.

Головний критерій накопичення знань, що впливає на ефективність діяльності органів публічної влади, полягає в їх цінності в інформаційному полі. Виділяють п'ять способів накопичення знань: 
- придбання - отримання знань із інших структурних підрозділів, використання консультантів, експертів;

- спеціалізовані ресурси джерела знань, де розміщується інформація з низки питань;

- злиття - формування проектних груп із включенням туди фахівців з різних сфер діяльності та з різним досвідом.

Структурні одиниці органів публічної влади, що орієнтовані на використання накопичених знань, досягають таких результатів:

- збільшують ефективність праці за рахунок прискорення процесу прийняття рішень на основі повноти відомостей, а також за рахунок зростання задоволеності співробітників. Серед застосовуваних технологій - наскрізний пошук всіх накопичених знань, інтеграція бізнес-процесів, інтерактивна взаємодія з керівниками;

- підвищують ефективність процесів за допомогою використання сучасних комунікаційних засобів (використовуються веб-служби);

- підвищують ефективність використання знань за допомогою налагодженої взаємодії швидкої обробки інформації та оперативних даних;

- демонструють підвищену ефективність використання інформаційно-комунікаційних технологій: покращена керованість, надійність, безпека i простота освоєння. Досягається за рахунок використання стандартного веб-інтерфейсу, мультимедійних засобів із використанням наявних мереж.

Таким чином, комунікаційну стратегію органів публічної влади можна розглядати як сукупність стратегій, які забезпечують ефективну взаємодію з іiї цільовою аудиторією, як всередині системи публічного управління, так і за іiі межами, що спрямовані на реалізацію загальної місії публічної політики.

\section{ВИСНОВКИ}

Комунікація в публічному управлінні $\epsilon$ дуже важливим інструментом у становленні демократичного суспільства, невід’ємним атрибутом публічної політики, де відкритість та прозорість публічного середовища потребує ефективних механізмів впровадження інформаційно-комунікаційними технологіями, що засновані на принципі зворотного зв'язку. Ураховуючи те, що держава оперує великим об'ємом даних, виникає потреба в більш ефективному управлінні ними. Упровадження електронного уряду має свої переваги. По-перше, це сприяє підвищенню прозорості діяльності органів публічної влади, по-друге - збільшує швидкість обслуговування за запитами громадян та бізнесу, по-третє - підвищує якість наданих державою послуг, по-четверте - сприяє спрощенню процедур при взаємодії органів публічної влади. 
Сьогодні сучасні інтернет-технології представляють великий інструментарій для спільного прийняття рішень. Існує безліч інтернетплатформ, що дозволяють ефективно організувати спільну роботу значного числа учасників над вирішенням проблеми. Багато із цих платформ використовують технології open-source, яке демонструє прихильність їх творців до ідей відкритості та демократії.

\section{АНОТАЦІЯ}

У статті розглянута природа комунікацій у публічному управлінні, обгрунтовано іiі роль у становленні демократичного суспільства. Сформовано алгоритм упровадження коректного вибору відповідної комунікаційної стратегії органів публічної влади, що дозволяє оптимізувати процеси вибору впровадження і застосування кращих ІКТ-рішень, підвищити ефективність їх використання, що дозволяє безперервно удосконалювати діяльність органів публічної влади за рахунок орієнтації даної системи на постійне поліпшення. Обгрунтовано важливість впровадження інформаційно-комунікаційних технологій у публічному управлінні, яка дозволяе обгрунтовано підійти до спільного прийняття рішень. Розглянуто способи накопичення знань, що мають вплив на ефективність діяльності органів публічної влади.

\section{ЛІТЕРАТУРА}

1. Стратегія сталого розвитку «Україна - 2020» [Текст] : схвалена Указом Президента України № 5/2015 від 12.01.2015 p. URL : https://zakon.rada.gov.ua/laws/show/5/2015 (дата звернення: 28.12.2020).

2. Schramm W. The process and effects of mass communication. University of Illinois Press, Urbana, 1954. 586p. (дата звернення: 28.12.2020).

3. Lasswell H. Propaganda technique in the World War. London, 1927. 250 р. (дата звернення: 28.12.2020).

4. Хабермас Ю. Моральное сознание и коммуникативное действие.СПб., 2000. 176с. (дата звернення: 28.12.2020).

5. Луман Н. Власть / Пер. с нем. А.Ю. Антоновского. Москва : Праксис, 2001. 256 с. (дата звернення: 28.12.2020).

6. Хакен Г. Информация и самоорганизация: макроскопический подход к сложным системам: пер. с англ. - 3-е изд., испр. и знач. доп. Москва : URSS: Ленанд, 2014. 317 с. (дата звернення: 28.12.2020).

7. Грачев М.Н. Политическая коммуникация: теоретические концепции, модели, векторы развития : монография. Москва : Прометей, 2004. С. 328. (дата звернення: 28.12.2020).

8. Тоффлер Э. Метаморфозы власти Пер. с анг. Москва : ООО «Изд-во АСТ», 2003. 669 с. (дата звернення: 28.12.2020). 
9. Weaver W., Shannon C. E. The mathematical theory of communication Univ. Of Illinois Press, 1963.131 р. (дата звернення: 28.12.2020).

10. Deutsch K. W. The Nerves of Government: Models of Political Communication and Control. London, Free Press of Glencoe, 1963. 316 p.

11. Яковлев И.П. Ключи к общению. Основы теории коммуникаций. Санкт-Петербург : Институт управления и экономики, 2001. 230 с. (дата звернення: 28.12.2020).

12. Меркулов И. Когнитивная эволюция. Рос. акад. наук. Ин-т философии. Москва : РОССПЭН. 310 с. (дата звернення: 28.12.2020).

13. Алмонд Г., Верба С. Гражданская культура: политические установки и демократия в пяти странах. Москва : Мысль, 2014. 500 с. (дата звернення: 28.12.2020).

14. Парсонс Т. Система современных обществ. Москва : АспектIIресс, 1998. 270 с. (дата звернення: 28.12.2020).

15. Меньшикова Г.А. Управление как вид коммуникации. Социальные коммуникации и информации исследования, образование, практика: материалы Межвузовской научно-практической конференции (11-12 ноября 1999 г., Санкт Петербург). Санкт-Петербург : ООО «Петрополис», 1999. С. 23-27. (дата звернення: 28.12.2020).

16. Пушкарева Г.В. Политический менеджмент в системе управленческих отношений современного общества. Вестник Моск. ун-та. Сер. 21. Управление (государство и общество). 2005. № 3. С. 62. (дата звернення: 28.12.2020).

17. Мазур В.Г. Комунікації як механізм взаємодії державних органів влади та громадськості на регіональному рівні. Електронний журнал «Державне управління: удосконалення та розвиток». URL : http://www.dy.nayka.com.ua/?op=1\&z=313 (дата звернення: 28.12.2020).

18. Погорелый Д. Политология / под общ. ред С.Н. Смоленского. Москва : Эксмо, 2008. 320 с. (дата звернення: 28.12.2020).

19. Бебик В.М. Інформаційно-комунікаційний менеджмент у глобальному суспільстві: психологія, технології, техніка паблік рилейшнз : монографія. Київ : МАУП, 2005. 440 с. (дата звернення: 28.12.2020).

20. Дрешпак В. М. Комунікації в публічному управлінні : навч. посіб. Дніпро : ДРІДУ НАДУ, 2015. - 168 с. (дата звернення: 28.12.2020).

21. Мельник А.Ф. Менеджмент державних установ і організацій : навч. посіб. / За ред. А.Ф. Мельник. Київ : ВД «Професіонал», 2006 р. 464 с. (дата звернення: 28.12.2020)

22. Шарков Ф.И. Политический консалтинг : учеб. пособ. Москва : Издательско-торговая кооперация «Дашков и К», 2004. 460 с. (дата звернення: 28.12.2020). 
23. Зверинцев А.Б. Коммуникационный менеджмент : рабочая книга менеджера PR.2-е изд., испр. Санкт-Петербург : Союз, 1997. 288c. (дата звернення: 28.12.2020).

24. Соловьев А.И. Политическая коммуникация: к проблеме теоретической идентификации. Полис. 2002. №3. С. 5-18. (дата звернення: 28.12.2020).

25. Друкер, Питер, Ф. Энциклопедия менеджмента. : Пер. с англ. Москав : Издательский дом «Вильямс». 2004. 321 с. (дата звернення: 28.12.2020).

26. Шпак Н.О. Основи комунікаційного менеджменту промислових підприємств. Львів : Видавництво Львівської політехніки, 2011. 328 с. (дата звернення: 28.12.2020).

27. Clift S. Putting, Pen to Paper: Electronic Democracy, Write On! 1996. URL : https://stevenclift.com/putting-pen-to-paper-electronicdemocracy-write-on-by-steven-clift-1996/ (дата звернення: 28.12.2020).

28. Дьякова Е.Г. Переход к электронному правительству: теоретические модели и национальные практики. Дніпропетровськ : Вісник Дніпропетровського Університету, 2013. С. 19-26. (дата звернення: 28.12.2020).

29. Амосов О. Електронне урядування - альтернативи не має! Новітні інформаційно-комунікаційні технології в модернізації публічного управління: зарубіжний і вітчизняний досвід : матеріали II наук.-практ. семінару, (25 квітня 2014 р., м. Дніпропетровськ) / редкол. : В.М. Дрешпак (голов. ред.). Дніпро : ДРІДУ НАДУ, 2014. 116 с. (дата звернення: 28.12.2020)

\section{Information about the authors:} Gavkalova N. L., Doctor of Economics, Professor, Head of the Department of Public Administration and Regional Economy Simon Kuznets Kharkiv National University of Economics 9a, Nauky avenue, Kharkiv, 61166, Ukraine

Jain Pradeep Kumar, Postgraduate Student at the Department of Public Administration and Regional Economy Simon Kuznets Kharkiv National University of Economics 9a, Nauky avenue, Kharkiv, 61166, Ukraine 